DOI: https://doi.org/10.47405/mjssh.v6i12.1184

\begin{tabular}{|c|c|}
\hline & Malaysian Journal of Social Sciences and Humanities (MJSSH) \\
\hline Malaysian Journal of & Volume 6, Issue 12, December 2021 \\
\hline (MJ-sSH) & e-ISSN : 2504-8562 \\
\hline & $\begin{array}{l}\text { Journal home page: } \\
\text { www.msocialsciences.com }\end{array}$ \\
\hline
\end{tabular}

\title{
Modul Kadimel: Reka Bentuk Pembangunan Modul Pembelajaran Kosa Kata Yang Lebif Afdal
}

\author{
Thibbah A/P Gatanagayan1, Fadzilah bte Amzah² \\ ${ }^{1}$ Kolej Vokasional Balik Pulau, Pulau Pinang, Malaysia \\ 2Pusat Pengajian Ilmu Pendidikan, Universiti Sains Malaysia (USM), Pulau Pinang, Malaysia \\ Correspondence: Thibbah a/p Gatanagayan (thibbah84@student.usm.my)
}

\begin{abstract}
Abstrak
Kajian awal membuktikan majoriti pelajar khususnya pelajar kolej vokasional tidak dapat membina ayat yang gramatis berdasarkan kosa kata yang sesuai selain menghadapi isu motivasi yang rendah dan bahan pembelajaran yang terhad bagi subjek Bahasa Melayu. Hal ini secara langsung akan mengganggu proses pembelajaran pelajar untuk menguasai kosa kata Bahasa Melayu dengan baik. Sehubungan itu, kajian ini bertujuan untuk membina sebuah modul yang berkesan dan interaktif bagi mengatasi masalah ketidakupayaan pelajar untuk mahir dalam kosa kata Bahasa Melayu dengan menerapkan elemen-elemen pembelajaran dalam aplikasi web Quizlet yang dapat membantu pelajar bermain sambil belajar dalam suasana yang tidak tertekan. Sebagaimana yang ditegaskan oleh Nailul dan Zaleha (2017), aplikasi Quizlet amat efektif dalam usaha untuk memperkaya kosa kata pelajar. Kad imbas elektronik yang dibangunkan melalui aplikasi Quizlet dikenali sebagai aplikasi web kad imbasan iaitu web-based flashcard program sesuai dalam pembelajaran kosa kata dengan mengekalkan informasi kosa kata dengan cara kreatif melalui pendedahan mod-mod yang menarik seperti mod Flashcards, Learn, Write, Spell, Test, Match, Gravity dan Live manakala penyelidik membangunkan mod kesembilan yang merupakan aktiviti binaan ayat dengan menggunakan 12 perkataan yang telah dipelajari dalam kad imbas elektronik. Pembinaan modul yang dikenali sebagai Modul Kadimel (singkatan bagi kad imbas elektronik) ini telah dibangunkan berdasarkan turutan dan langkah dalam Model ADDIE dengan mengintegrasikan teknologi dan media dalam pengajaran dan pembelajaran. Melalui kajian ini diharap modul berbantukan multimedia ini dapat meningkatkan pencapaian kosa kata bagi pembelajaran Bahasa Melayu selain membantu pelajar mengekalkan informasi kosa kata dengan cara kreatif.
\end{abstract}

Kata kunci: kosa kata, modul, multimedia, aplikasi Quizlet, model ADDIE

\section{Kadimel Module: Development Design of Extensive Vocabulary Learning Module}

\begin{abstract}
Preliminary studies proved that the majority of students, especially vocational college students, could not construct grammatical sentences based on appropriate vocabulary apart from facing issues of low motivation and limited learning materials for Malay language subjects. This will directly interfere with the learning process of students to master the Malay vocabulary well. Accordingly, this study aims to build an effective and interactive module to overcome the inability of students to be proficient in Malay vocabulary by applying learning elements in the Quizlet web application that can help students play while learning in a non-stressful environment. As pointed out by Nailul and Zaleha (2017), Quizlet
\end{abstract}


application is very effective in efforts to enrich students 'vocabulary. The electronic flashcard developed through Quizlet application is known as scan card web application which is a web-based flashcard program suitable in vocabulary learning by maintaining vocabulary information in a creative way through exposure of interesting modes such as Flashcards, Learn, Write, Spell, Test, Match, Gravity and Live while the researchers developed the ninth mode which is a sentence construction activity using 12 words that have been learned in an electronic flashcard. The construction of this module known as Kadimel Module (short for kad imbas elektronik) was developed based on the sequence and steps in the ADDIE Model by integrating technology and media in teaching and learning. Through this study, it is hoped that this multimedia -assisted module can improve vocabulary achievement for learning Malay as well as help students maintain vocabulary information in a creative way.

Keywords: vocabulary, modules, multimedia, Quizlet application, ADDIE model

\section{Pengenalan}

Seperti bahasa-bahasa yang lain, seseorang perlu mempunyai asas pengetahuan kosa kata yang baik untuk membolehkan mereka mempunyai kemahiran komunikasi yang baik, terutamanya dalam aktivitiaktiviti akademik. Wilkins (1972) menyatakan, "without grammar very little can be conveyed, without vocabulary nothing can be conveyed." Hal ini jelas menunjukkan betapa pentingnya pembelajaran kosa kata terutamanya dalam menyampaikan sesuatu maklumat mahupun mesej. Elemen ini juga sejajar dengan salah satu kemahiran dalam Dokumen Standard Kurikulum Kolej Vokasional (2018) yang menekankan aspek tatabahasa yang juga memperlihatkan penggabungjalinan kemahiran bahasa.

Dalam era pendidikan kontemporari, pelbagai inovasi telah dibangunkan bagi meningkatkan penglibatan pelajar dengan memasukkan elemen multimedia dan teknologi dalam pembelajaran. Pembelajaran menggunakan teknologi multimedia adalah berasaskan komputer, pembelajaran berasaskan Internet, pembelajaran berasaskan web, pembelajaran berasaskan youtube, pembelajaran dalam talian, pembelajaran maya atau virtual learning environment (VLE) (Sarimah, 2015). Siti Masrah (2017) berpendapat penggunaan TMK dalam pengajaran dan pembelajaran di sekolah dapat meningkatkan penguasaan bahasa dalam kalangan pelajar.

Pengajaran Bahasa Melayu juga tidak terkecuali daripada pengaruh TMK kerana penggunaan TMK dalam sesi PdP Bahasa Melayu berupaya meningkatkan lagi keupayaan pelajar dalam menguasai Bahasa Melayu dengan lebih baik. Hal ini dibuktikan dalam kajian Fatimah Jafri (2017) yang menunjukkan bahawa pengintegrasian TMK dalam PdP secara terancang dan berterusan adalah penting untuk membentuk, meningkatkan minat dan tahap kefahaman serta kualiti pembelajaran dalam kalangan pelajar. Justeru, kajian ini bertujuan untuk menganalisis permasalahan yang berlaku dan mencadangkan sebuah modul pembelajaran bagi menangani permasalahan ini.

\section{Objektif Kajian}

Secara khususnya kajian ini adalah untuk mereka bentuk dan membangunkan Modul Kadimel bagi subjek kosa kata Bahasa Melayu dalam kalangan pelajar kolej vokasional.

\section{Sorotan Literatur}

\section{Kosa Kata}

Kosa kata amat penting kerana berfungsi sebagai instrumen pemikiran untuk menyampaikan sesuatu makna ataupun mesej seseorang (Amelia, 2017). Pembelajaran kosa kata sama pentingnya dengan 
pembelajaran dan penguasaan kemahiran serta pengetahuan bahasa dalam meningkatkan kecekapan dan kemahiran berbahasa pelajar. Menurut Nailul dan Zaleha (2017), dengan memahami 2,000 patah perkataan yang paling biasa digunakan, seseorang pelajar akan dapat memahami $80 \%$ daripada kandungan teks tersebut. Peratusan tersebut meningkat sehingga $96 \%$ jika merangkumi perkataan yang pernah ditemui dalam konteks pertuturan dan bacaan secara tidak formal. Lantas pengetahuan dan penguasaan kosa kata yang banyak dapat membantu penutur dalam mempelajari dan memahami sesuatu bahasa dengan lebih baik. Berdasarkan kesemua definisi di atas, dapat dirumuskan bahawa kosa kata terdiri daripada perkataan-perkataan dalam mengungkap pemikiran dan menjadikan komunikasi lebih efektif serta berkesan justeru seseorang perlu kompeten dalam mempelajari kosa kata.

Vargas (2011) juga menegaskan adalah mustahak untuk mengenal pasti masalah pelajar dalam pembelajaran bahasa dan menyelesaikannya secepat yang mungkin. Kemungkinan aspek teknologi merupakan jalan penyelesaian yang terbaik bagi masalah pelajar kerana teknologi dapat membantu dalam memotivasikan pelajar, mencapai kesemua pendekatan pembelajaran dan juga membantu pelajar dalam melalui pengalaman yang nyata. Kenyataan ini disokong oleh kajian Dewi Kartika dan Sharifah afsah (2018) yang mendapati pelajar lebih teruja untuk belajar sekiranya guru menggunakan bahan dan peralatan multimedia dalam proses PdP. Dapatan kajian juga menunjukkan pelajar berasa seronok mengikuti pelajaran yang dirancang. Pelajar bukan sahaja mampu meningkatkan kosa kata mereka, tetapi dapat mencari makna perkataan secara kendiri dan menggunakan kosa kata dalam konteks 50 ayat yang dibina. Menurut Norlizawaty (2019), ternyata pengajaran dan pembelajaran kaedah tradisional dan kurang mencabar berupaya membosankan generasi celik TMK kerana mereka mengharapkan tahap interaktif yang tinggi. Justeru, cara interaktif dan menarik perlu diteroka bagi menggalakkan pembelajaran kosa kata yang efisien.

\section{Motivasi}

Bagi pembelajaran Bahasa Melayu, motivasi para pelajar untuk mempelajari bahasa ini masih dapat dipengaruhi oleh faktor-faktor intrinsik dan ekstrinsik, seperti peranan tenaga pengajar dan persekitaran (Zaliza \& Zaitul, 2014). Model ARCS dalam reka bentuk instruksi adalah pendekatan yang mudah digunakan untuk meningkatkan tarikan motivasi dalam instruksi. ARCS menyediakan kerangka yang kuat untuk mereka bentuk dan meningkatkan mutu motivasi dalam berbagai-bagai entiti seperti pengajaran di bilik darjah, penyediaan bahan Internet, serta bahan PdP (Sriadhi, 2015; Sangeeta, 2014). Kajian terdahulu oleh Mahalechumy (2015) menunjukkan pembelajaran berasaskan multimedia iaitu Short Message Services (SMS) telah diaplikasikan untuk mengkaji tahap motivasi pelajar dalam pembelajaran bahasa dalam kalangan pelajar universiti. Dapatan menunjukkan terdapat hubungan yang signifikan antara variabel motivasi iaitu perhatian (attention), kerelevanan (relevance), keyakinan (confidence) dan kepuasan (satisfaction). Bagi skop kajian ini, model ARCS dilihat sebagai satu pendekatan yang bersesuaian bagi mengkaji cara Modul Kadimel yang berasaskan aplikasi web Quizlet dalam meningkatkan motivasi para pelajar vokasional untuk mempelajari Bahasa Melayu khususnya bagi aspek kosa kata. ARCS menyediakan kerangka yang baik kepada penyelidik mereka bentuk intervensi pembelajaran yang dapat meningkatkan mutu motivasi dalam pelbagai bentuk aplikasi, termasuklah aplikasi-aplikasi berasaskan Internet (Sriadhi, 2015) seperti platform Quizlet. Oleh itu, penyelidik akan membina Modul Kadimel yang interaktif bagi meningkatkan tahap motivasi yang terdiri daripada elemen-elemen seperti ARCS untuk memperlihatkan hubungan signifikan yang kuat.

\section{Adaptasi Teori Kognitif Pembelajaran Multimedia Dalam Pembinaan Modul Kadimel}

Saluran visual dan verbal memainkan peranan yang penting untuk menyampaikan maklumat dalam pembinaan Modul Kadimel. Maklumat ini akan menghasilkan maklumat asas imej yang akan disusun ke dalam model visual dan berlaku proses penyusunan maklumat visual manakala perkataan yang diucapkan memasuki sistem kognitif melalui telinga dan diproses dalam saluran verbal atau auditori. Proses pengintegrasian maklumat pula akan berlaku apabila maklumat dalam model visual dan verbal serta pengetahuan sedia ada pelajar dikaitkan antara satu sama lain dalam sistem ingatan kerja manusia. Pengadaptasian teori ini yang melibatkan saluran visual dan auditori, melibatkan ketiga-tiga proses 
kognitif semasa pembelajaran multimedia seperti memilih, menyusun dan mengintegrasikan maklumat (Mayer, 2014).

Proses pembelajaran multimedia berlaku dalam ingatan kerja atau ingatan jangka pendek yang menyimpan dan memanipulasi maklumat secara aktif dalam masa sangat singkat (Mayer, 2014). Pengintegrasian teori kognitif pembelajaran multimedia ke dalam modul Kadimel akan memperlihatkan otak pelajar memproses maklumat yang diterima dalam subsistem saraf. Ini menggambarkan empat prinsip daripada kajian dalam sains kognitif (Mayer, 2014), iaitu : (1) pemprosesan maklumat bentuk visual dan auditori dalam saluran yang berasingan (dual-channel), (2) melakukan pemprosesan pada sebahagian maklumat di setiap saluran dalam satu masa (limited capacity), (3) pembelajaran berlaku ketika pelajar terlibat dalam proses pembelajaran, seperti memilih bahan, menyusun dan mengintegrasikan dengan pengetahuan sedia ada (active processing), dan (4) mengintegrasikan pengetahuan baharu dan keupayaan sedia ada dari ingatan jangka panjang untuk mewujudkan kebolehan yang berkesan (transfer).

Berasaskan Teori Kognitif Pembelajaran Multimedia, Mayer (2014) mengatakan gabungan teks dan gambar adalah lebih baik berbanding hanya paparan teks atau gambar sahaja. Ingatan memori akan lebih kekal lama jika seseorang didedahkan dengan bahan yang dipaparkan dengan kombinasi gambar dan audio. Kenyataan ini menyokong dapatan kajian Nur Fatin et al. (2021) yang membuktikan penggunaan elemen multimedia mampu menambah kefahaman pelajar sepanjang proses pengajaran dan pembelajaran di dalam kelas. Hal ini kerana pelajar akan lebih faham sekiranya guru menggunakan sesuatu bahan yang bergambar berbanding penggunaan teks semata-mata kerana suatu pengajaran yang berasaskan naratif memerlukan tempoh masa tertentu bagi membolehkan pelajar mengingat isi-isi penting dalam huraian yang diberikan. Dengan adanya elemen animasi, video dan audio, proses pembelajaran akan menjadi lebih menarik selain dapat mengelakkan rasa bosan dalam kalangan pelajar.

\section{Metod Kajian}

Kajian ini bertujuan untuk membina sebuah modul yang sesuai dan interaktif bagi menyokong proses pembelajaran dan pengajaran penguasaan aspek kosa kata Bahasa Melayu. Dalam kajian ini, pengkaji memilih model ADDIE sebagai pendekatan sistematik dalam membangunkan Modul Kadimel melalui aplikasi web Quizlet. Pembentukan Modul Kadimel ini melibatkan lima fasa berdasarkan Model ADDIE iaitu analisis (analyze), reka bentuk (design), pembangunan (development), pelaksanaan (implementation) dan penilaian (evaluation). Branch (2009) menjelaskan model ADDIE menjadi satu proses asas dalam pembinaan sumber pembelajaran yang berkesan dan sesuai dilaksanakan dalam sistem pendidikan serta pembelajaran yang lain.

Prinsip asas ADDIE ialah kesemua aktiviti yang dirancang adalah ke arah membimbing pelajar kerana pelajar membina pengetahuan dalam ruang pembelajaran. Rajah 1 di bawah menunjukkan rajah model ADDIE.

Model ini merupakan model pengajaran interaktif dan melalui pendekatan model ini, proses semakan boleh berlaku pada setiap fasa dan ini membantu penyelidik untuk melihat semula fasa-fasa terbabit bagi membuat penambahbaikan. Proses semakan ini berulang sehinggalah terhasil sebuah modul pengajaran yang mantap dan berkesan. 
Rajah 1: Model ADDIE

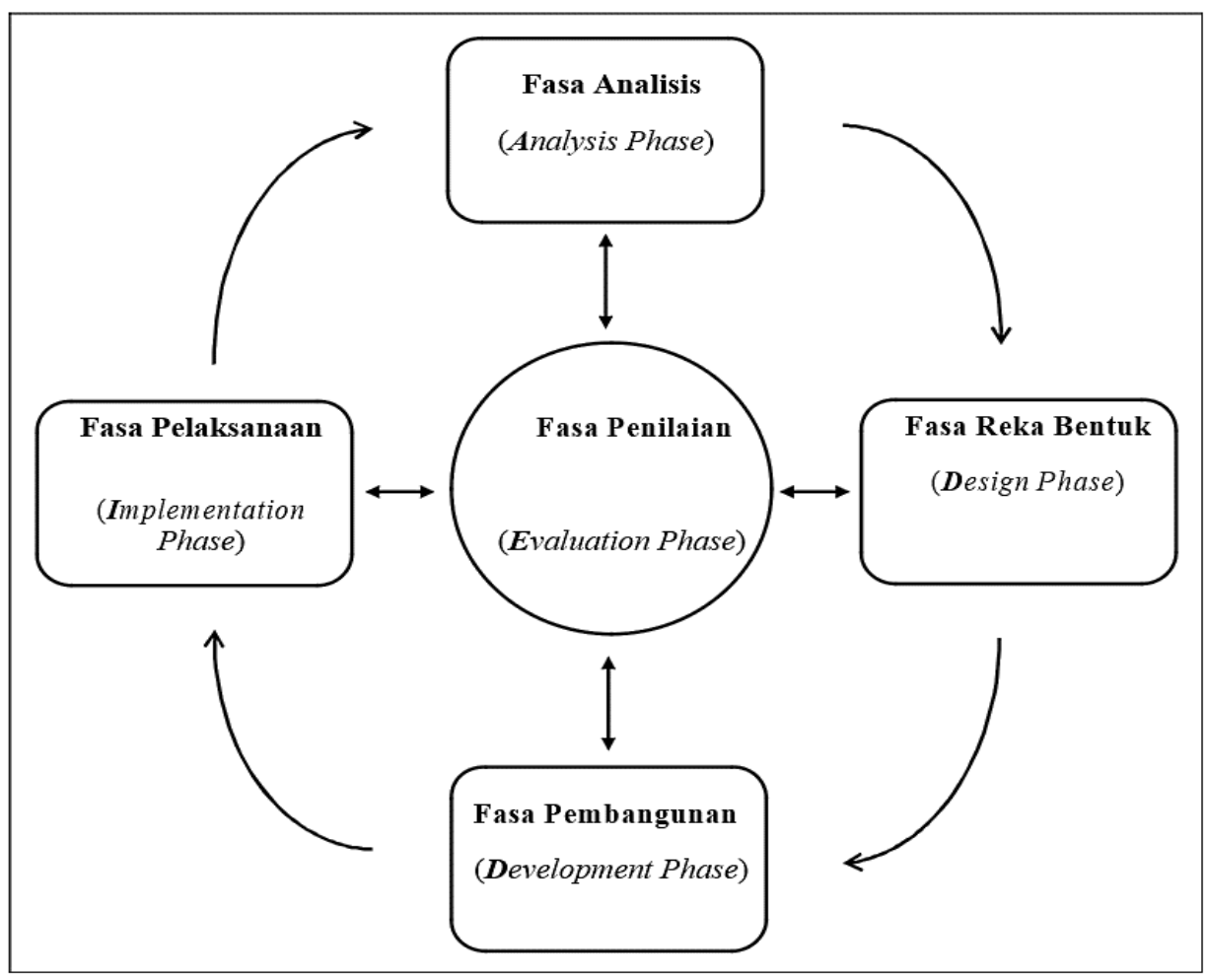

Sumber: Branch (2009)

\section{Hasil Kajian}

\section{Reka Bentuk Pembinaan Modul Kadimel}

Modul Kadimel yang mengandungi mod-mod interaktif telah dibangunkan berasaskan model ADDIE dengan mengaplikasikan kelima-lima fasa iaitu (1) fasa analisis (Analysis), (2) fasa reka bentuk (Design), (3) fasa pembangunan (Development), (4) fasa pelaksanaan (Implementation) dan (5) fasa penilaian (Evaluation). Dapatan mengikut fasa dipaparkan seperti berikut;

\section{Fasa Analisis (Analysis)}

Modul Kadimel Langkah pertama yang perlu dijalankan dalam mereka bentuk modul pengajaran mengikut fasa ADDIE ialah melakukan analisis terhadap perkara yang berkaitan dengan modul yang hendak dihasilkan seperti pelajar, kandungan pelajaran dan aspek pengajaran guru. Menurut Branch (2009), fasa analisis dilaksanakan untuk mengenal pasti masalah berdasarkan dua isu iaitu masalah dalam pengajaran dan pembelajaran serta cara untuk mengatasi masalah yang telah dikenal pasti. Analisis keperluan telah dijalankan melalui beberapa cara antaranya ialah melalui; 1) Borang tinjauan bagi memperoleh maklumat peperiksaan PT3, 2) Borang soal selidik, 3) Kuiz Kosa Kata; dan 4) Dokumen-dokumen yang berkaitan dengan kurikulum Bahasa Melayu Kolej Vokasional.

Bagi mengetahui tahap pencapaian dan pengetahuan sedia ada pelajar terhadap subjek Bahasa Melayu, maklumat pencapaian pelajar dalam Peperiksaan Tingkatan 3 (PT3) diperoleh melalui borang tinjauan yang diedarkan di dua buah kolej vokasional. Jadual 1 menunjukkan pencapaian pelajar di dua buah kolej vokasional di Johor Bahru ambilan 2019 berdasarkan pencapaian PT3 bagi subjek Bahasa Melayu. 
Jadual 1: Keputusan PT3 bagi Pelajar Tahun Satu Sijil Vokasional Malaysia (SVM) di dua buah kolej vokasional Johor Bahru

\begin{tabular}{cccc}
\hline Gred & $\begin{array}{c}\text { Kolej Vokasional A } \\
\text { (bilangan pelajar) }\end{array}$ & $\begin{array}{c}\text { Kolej Vokasional B } \\
\text { (bilangan pelajar) }\end{array}$ & Jumlah Pelajar \\
\hline $\mathrm{A}$ & 22 & 24 & 46 \\
$\mathrm{~B}$ & $(19.81 \%)$ & $(15.89 \%)$ & 82 \\
$\mathrm{C}$ & $(35.13 \%)$ & 43 & \\
$\mathrm{C}$ & 35 & $(28.47 \%)$ & 91 \\
$\mathrm{D}$ & $(31.53 \%)$ & 56 & 41 \\
& 13 & $(37.08 \%)$ & 2 \\
E & $(11.71 \%)$ & $(18.54 \%)$ & 262 \\
\hline
\end{tabular}

Berdasarkan borang tinjauan maklumat peperiksaan PT3, jelas membuktikan pelajar-pelajar di dua buah kolej vokasional di Johor Bahru memperoleh keputusan yang kurang cemerlang dalam subjek Bahasa Melayu dalam peperiksaan PT3. Hal ini ditunjukkan melalui bilangan pelajar yang mencatatkan keputusan gred $\mathrm{C}$ dan ke bawah berjumlah 134 dari keseluruhan 262 pelajar bagi keduadua buah kolej vokasional di Johor Bahru.

Seterusnya, borang soal selidik kertas pensil yang diedarkan kepada pensyarah-pensyarah Bahasa Melayu di kolej vokasional juga menunjukkan adanya keperluan intervensi kepada pelajar tahun 1 kolej vokasional untuk meningkatkan tahap pencapaian kosa kata dan motivasi pelajar bagi subjek Bahasa Melayu. Dapatan soal selidik secara ringkasnya menunjukkan responden memberi maklum balas mengenai isu-isu PdP Bahasa Melayu di kolej vokasional seperti berikut:

a) Pelajar kolej vokasional memperoleh keputusan yang sederhana bagi subjek Bahasa Melayu $(95 \%)$

b) Tahap pencapaian pelajar bagi subjek Bahasa Melayu di kolej vokasional tidak memuaskan $(82 \%)$

c) Pelajar tidak dapat membina ayat yang gramatis dan bermakna dengan menggunakan kosa kata yang sesuai $(80 \%)$

d) Tahap motivasi pelajar dalam pembelajaran Bahasa Melayu terutamanya bagi aspek tatabahasa adalah rendah $(92 \%)$

e) Tidak ada keseragaman dalam penggunaan buku atau bahan dalam mengendalikan proses PdP Bahasa Melayu di seluruh kolej vokasional (92.3)

f) Pelajar tidak disediakan buku teks Bahasa Melayu mengikut Kurikulum Standard Kolej Vokasional (75\%)

g) Pensyarah subjek mengalami masalah untuk mengendalikan sesi PdP Bahasa Melayu (71.8\%)

Isu-isu ini sememangnya membuktikan pentingnya kajian ini dilaksanakan kerana hal ini secara langsung memberi impak yang negatif kepada para pelajar mahupun pensyarah. Dapatan-dapatan ini sememangnya menunjukkan perlunya pembinaan Modul Kadimel untuk dijadikan sebagai panduan umum bagi sesi PdP Bahasa Melayu di kolej vokasional. Selain itu, dapatan markah daripada kuiz kosa kata dalam kajian awal juga menunjukkan tahap pengetahuan pelajar masih lemah. Jadual 2 menunjukkan pencapaian pelajar kolej vokasional dalam kuiz kosa kata tersebut.

Berdasarkan analisis pencapaian pelajar dalam kuiz tersebut, didapati 64 orang pelajar daripada 106 orang pelajar gagal. Hal ini bermaksud hanya 42 pelajar yang lulus dan ini menunjukkan peratus lulus hanya $39.6 \%$ manakala peratus pelajar gagal pula ialah $60.4 \%$. Majoriti pelajar didapati tidak dapat membina ayat yang gramatis dengan menggunakan beberapa perkataan. Kebanyakan ayat yang dibina oleh pelajar ialah ayat tunggal dan kurang bermakna. Oleh itu, pelaksanaan kaedah alternatif yang 
sesuai dalam sesi PdP Bahasa Melayu terutamanya dalam aspek kosa kata adalah wajar dan bertepatan dengan saranan KPM yang menekankan kompetensi aplikasi sistem bahasa dalam DSK.

Jadual 2: Pencapaian pelajar kolej vokasional dalam Kuiz Kosa Kata di dua buah kolej vokasional di Johor Bahru dan Butterworth.

\begin{tabular}{lcccccccccccccc}
\hline & \multicolumn{10}{c}{ Gred Pencapaian (Kolej Vokasional) } \\
\cline { 2 - 16 } Kolej & $\mathbf{1 0 0}$ & $\mathbf{8 9}$ & $\mathbf{7 9}$ & $\mathbf{6 9}$ & $\mathbf{6 4}$ & $\mathbf{5 9}$ & $\mathbf{5 4}$ & $\mathbf{4 9}$ & $\mathbf{4 4}$ & $\mathbf{3 9}$ & $\mathbf{3 4}$ & \\
& $\mathbf{9 0}$ & $\mathbf{8 0}$ & $\mathbf{7 0}$ & $\mathbf{6 5}$ & $\mathbf{6 0}$ & $\mathbf{5 5}$ & $\mathbf{5 0}$ & lulus & $\mathbf{4 5}$ & $\mathbf{4 0}$ & $\mathbf{3 5}$ & $\mathbf{0}$ & gagal \\
& A & A- & B+ & B & B- & C+ & C & & D+ & D & D- & E & \\
\hline A & & & & 2 & 2 & & 1 & 5 & 1 & 4 & 10 & 39 & 54 \\
B & 1 & 3 & 7 & 11 & 7 & 8 & 37 & 7 & & 3 & & 10 \\
Jum & 1 & 3 & 9 & 13 & 7 & 9 & 42 & 8 & 4 & 13 & 39 & 64 \\
\hline
\end{tabular}

Kesimpulannya, fasa analisis yang telah dilakukan untuk kajian ini adalah dengan mengenal pasti masalah, cabaran dan keperluan pelajar yang akan dijadikan sebagai garis panduan untuk mereka bentuk Modul Kadimel. Oleh itu, kepentingan fasa analisis ini adalah untuk mendapatkan gambaran sebenar bagi mereka bentuk aktiviti supaya modul yang dihasilkan lebih berkesan dan efektif.

\section{Fasa Reka Bentuk (Design)}

Fasa ini menjelaskan pandangan keseluruhan mengenai pembentukan matlamat dan objektif modul, pengurusan senarai aktiviti, dan membina kaedah penilaian (Branch, 2009). Fasa ini juga akan menjelaskan teori yang diaplikasikan dalam modul ini.

\section{a. Pembentukan Matlamat dan Objektif Modul}

Matlamat pembinaan Modul Kadimel ini adalah berdasarkan kriteria pencapaian yang digariskan dalam DSK BM semester satu tahun satu. Matlamat umumnya ialah pelajar dapat memahami dan menggunakan bentuk kata yang sesuai dalam pelbagai bidang. Matlamat khusus pula ialah pelajar dapat mengenal pasti dan menggunakan bentuk kata tunggal, kata terbitan dan kata majmuk dengan betul mengikut konteks. Selain itu, pelajar dapat membina ayat yang tepat dan gramatis dengan menggunakan kata tunggal, kata majmuk dan kata terbitan.

\section{b. Pengurusan Senarai Aktiviti}

Pengurusan senarai aktiviti merangkumi susunan reka bentuk modul yang melibatkan proses mereka bentuk dan menghasilkan modul. Pengkaji memasukkan lapan aktiviti berdasarkan mod-mod yang terdapat dalam aplikasi Quizlet iaitu Flashcards (kad imbasan), Learn (latih tubi 1), Write (latih tubi 2), Spell (latihan mengeja), Test (penilaian), Match (permainan bahasa 1), Gravity (permainan bahasa 2) dan Live (permainan kolaboratif) ke dalam Modul Kadimel yang dikaitkan dengan kriteria pencapaian dalam KSKV. Rajah 2 menunjukkan persembahan maklumat untuk reka bentuk utama aplikasi Quizlet.

Selain aktiviti-aktiviti ini, Modul Kadimel juga menyediakan dua lembaran kerja tambahan yang memfokuskan binaan ayat berdasarkan perkataan yang dipelajari daripada setiap set. 
Rajah 2: Skrin Utama Aplikasi Quizlet

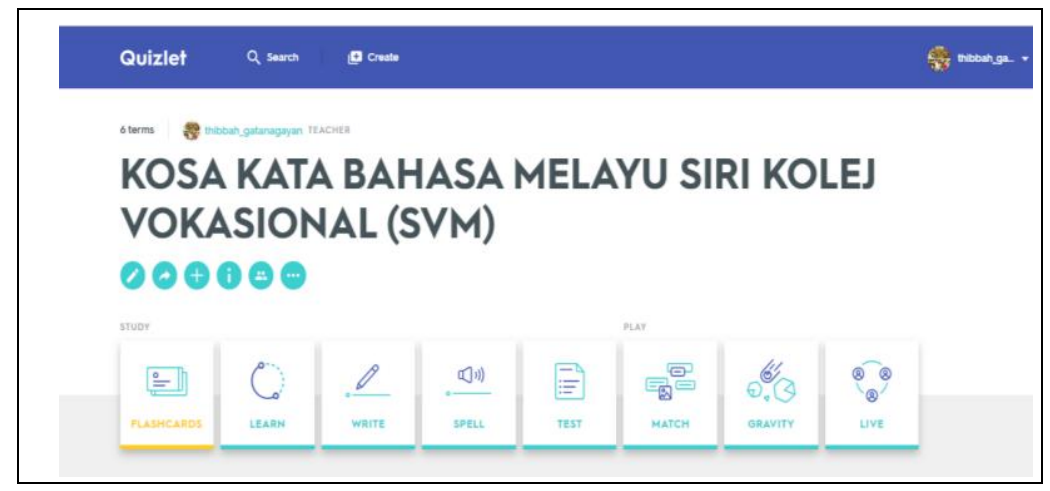

\section{c. Membina Kaedah Penilaian}

Proses yang seterusnya ialah membina item-item dalam menilai prestasi pelajar yang menyediakan maklum balas terhadap keberkesanan sesuatu modul yang direka bentuk. Pada peringkat ini, pengkaji menggunakan dua instrumen kajian dalam menilai keberkesanan Modul Kadimel terhadap pencapaian kosa kata dan motivasi pelajar dan antaranya iaitu 1) Soalan Ujian Pra, Ujian Pos dan Ujian Pos Lanjutan dan; 2) Borang Soal selidik Motivasi (ARCS). Sebanyak tiga set ujian disediakan dan setiap set mempunyai 24 soalan. Pembinaan item-item bagi soal selidik pula adalah berdasarkan Model ARCS yang diadaptasi dan merangkumi 20 item.

\section{d. Teori Pembelajaran}

Teori pembelajaran yang menjadi landasan dalam kajian ini ialahTeori Kognitif Pembelajaran Multimedia Mayer. Dengan adanya mod-mod yang menarik seperti flashcards, Learn, Match, Gravity dan sebagainya dalam modul dapat mempercepatkan proses ingatan dan ini selari dengan saranan oleh Mayer dan Moreno (2003) dan Mayer (2014) yang menegaskan bahawa maklumat grafik lebih mudah diingat kembali berbanding maklumat teks selain meningkatkan pencapaian pelajar dan secara tidak langsung dapat mengurangkan beban kognitif pelajar. Selain itu, Modul Kadimel yang berbantukan multimedia dapat membantu pelajar dalam membina pengetahuan baru, mencari maklumat, terlibat di dalam perbincangan, serta menghasilkan atau mengolah idea sedia ada untuk pembelajaran yang lebih baik.

Pengaplikasian multimedia dalam pengajaran dan pembelajaran juga mampu meningkatkan kadar ketekalan ingatan pelajar dan hal ini telah disokong oleh kajian Baity (2019), Hung et al., (2018) dan Sriadhi (2015). Sememangnya Modul Kadimel yang tergolong dalam pembelajaran multimedia dapat mempercepatkan proses ingatan bagi jangka masa panjang. Sebagai contoh, ingatan pelajar menjadi lebih kukuh apabila mereka didedahkan dengan imej dan maksud bagi sesuatu perkataan melalui mod yang pertama iaitu flashcards dalam bentuk kad imbas elektronik dan diikuti dengan mod-mod interaktif yang lain seperti match, gravity dan lain-lain.

\section{Fasa Pembangunan (Development)}

Fasa yang seterusnya ialah fasa pembangunan dan merujuk Branch (2009), peringkat ini bertujuan untuk membina dan mengesahkan sumber kajian, membina kandungan, menentukan media, membina garis panduan kepada pelajar, melaksanakan semakan formatif dan melaksanakan kajian rintis.

\section{a. Binaan Kandungan}

Aktiviti-aktiviti dalam modul ini direka bentuk mengikut standard kandungan yang ditetapkan dalam Kurikulum Standard Kolej Vokasional Bahasa Melayu bagi semester 1. Dalam pada itu, modul yang dibangunkan ini juga merangkumi aktiviti bahasa berbentuk pembelajaran aktif yang sangat menarik dan mudah untuk dilakukan oleh pelajar. Justeru, pengkaji menetapkan objektif yang boleh dicapai dan 
seterusnya menyenaraikan, memilih dan menyaring isi kandungan yang ingin dimuatkan dalam modul. Secara keseluruhannya, modul ini mengandungi 27 aktiviti iaitu 9 aktiviti bagi setiap unit. Jumlah unit dalam modul ini ialah tiga unit.

\section{b. Pemilihan Media}

Proses yang seterusnya dalam fasa ini ialah memilih media yang sesuai untuk melaksanakan proses pengajaran dan pembelajaran. Secara keseluruhannya, sesi PdP dilaksanakan melalui perisian Camtasia versi 19.0 yang menggabungkan kesemua kandungan media yang telah dibina iaitu bahan media berbentuk teks dan grafik dalam slaid. Kod QR juga telah dibangunkan bagi setiap set pembelajaran yang sememangnya mengikut trend terkini dan mudah diakses di mana-mana sahaja. Rajah 3 sehingga rajah 16 menunjukkan paparan skrin daripada aplikasi ini yang menunjukkan mod-mod yang memudahkan pelajar untuk menguasai kosa kata dengan mudah serta mengurangkan beban kognitif pelajar untuk mempelajari tajuk ini.

Rajah 3: Skrin Mod 1 (flashcard)

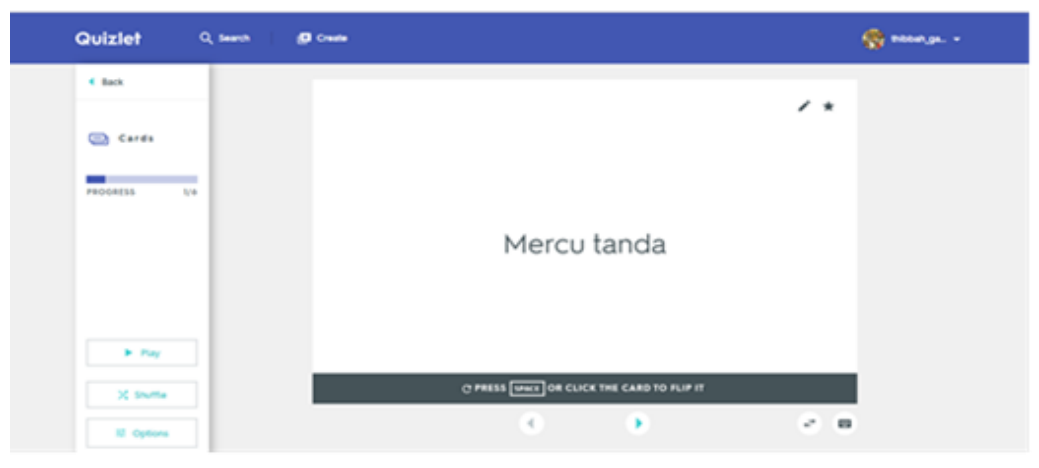

Rajah 4: Skrin Mod 1 (flashcard) maksud perkataan

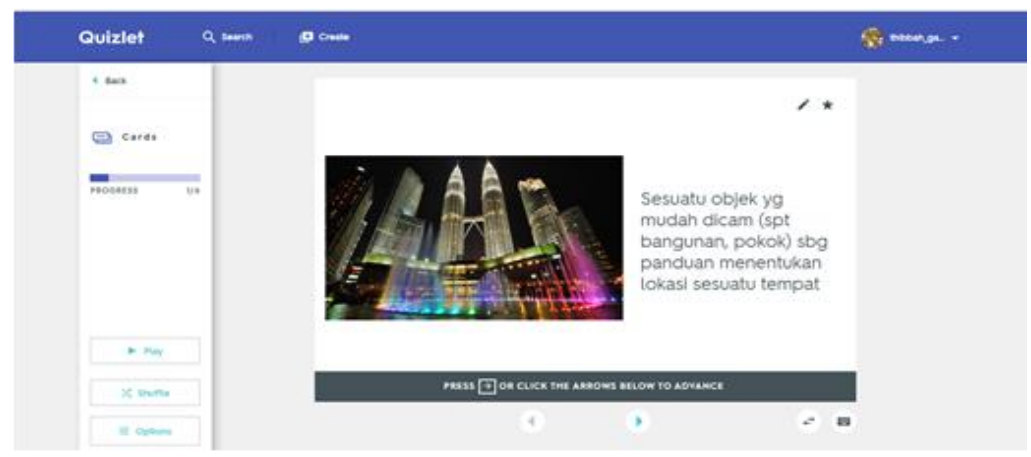

Rajah 5: Skrin Mod 2 (learn)

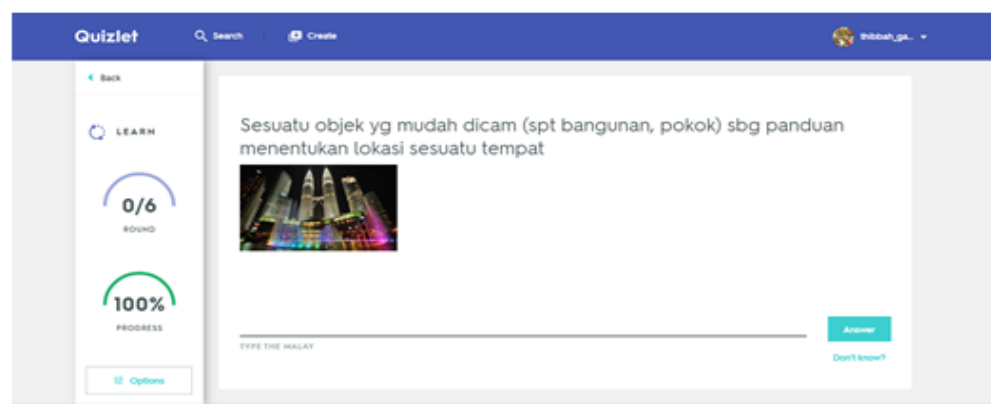


DOI: https://doi.org/10.47405/mjssh.v6i12.1184

Rajah 6: Skrin Mod 2 (learn) maklum balas Pengukuhan

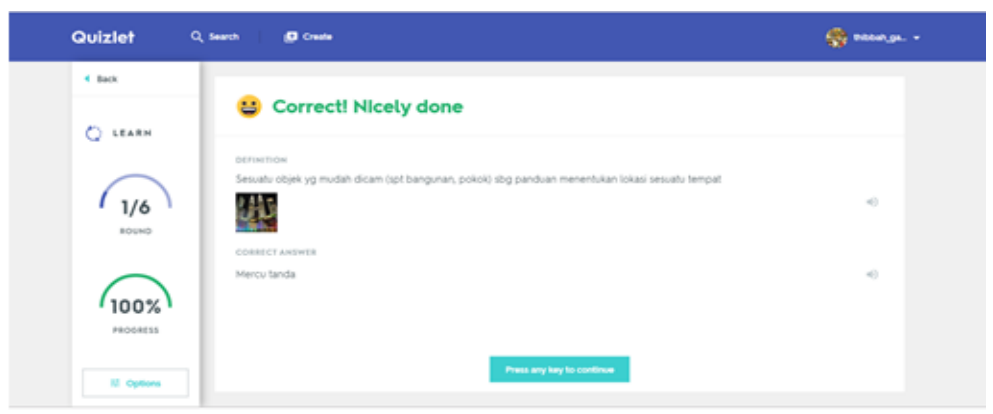

Rajah 7: Skrin Mod 3 (write)

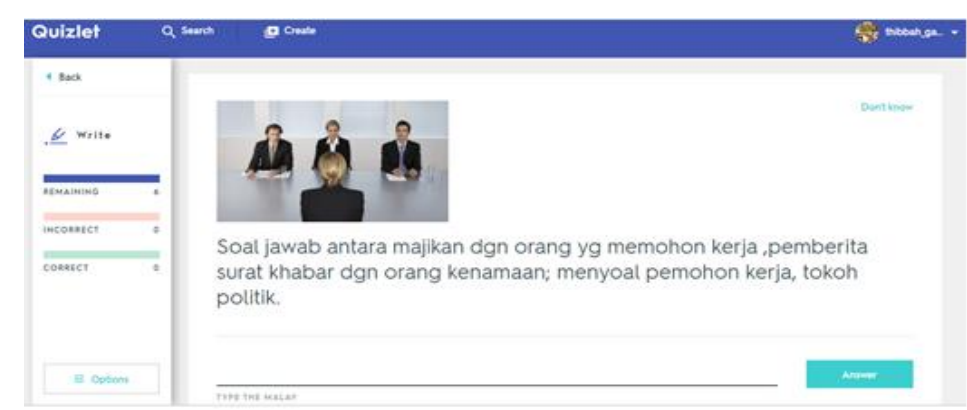

Rajah 8: Skrin Mod 3 (write) maklum balas pengukuhan

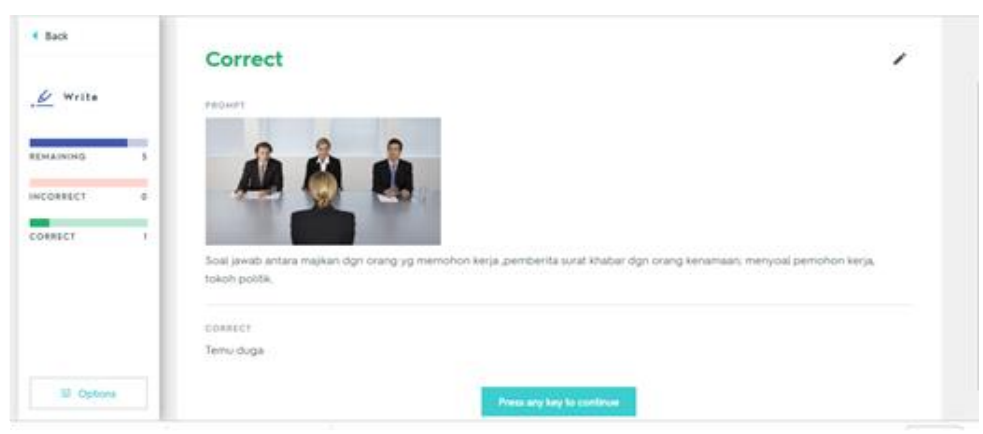

Rajah 9: Skrin Mod 4 (spell)

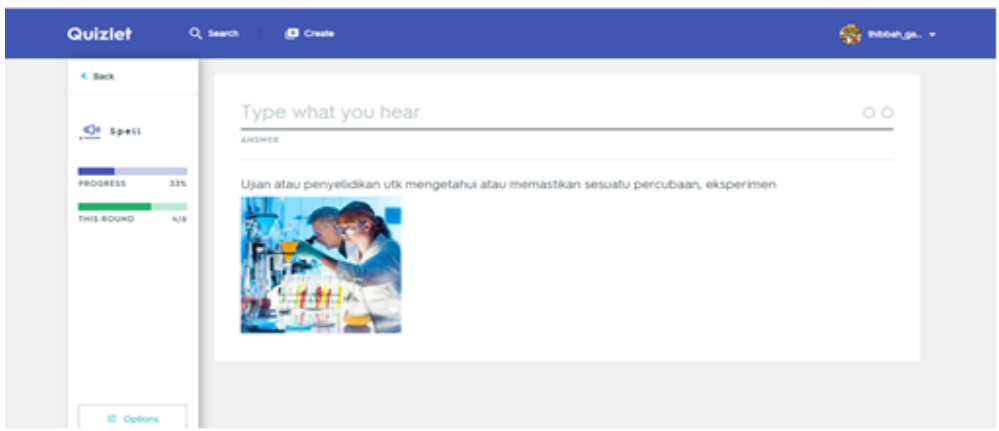



DOI: https://doi.org/10.47405/mjssh.v6i12.1184

Rajah 10: Skrin Mod 5 (test)

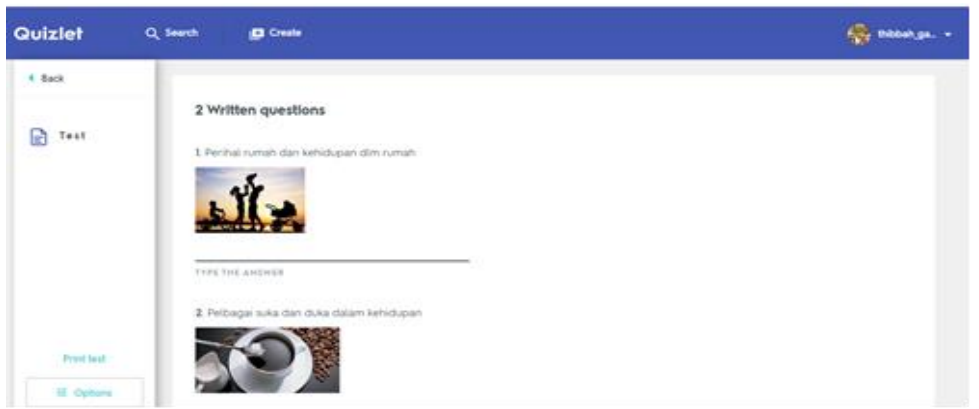

Rajah 11: Skrin Mod 5 (test)

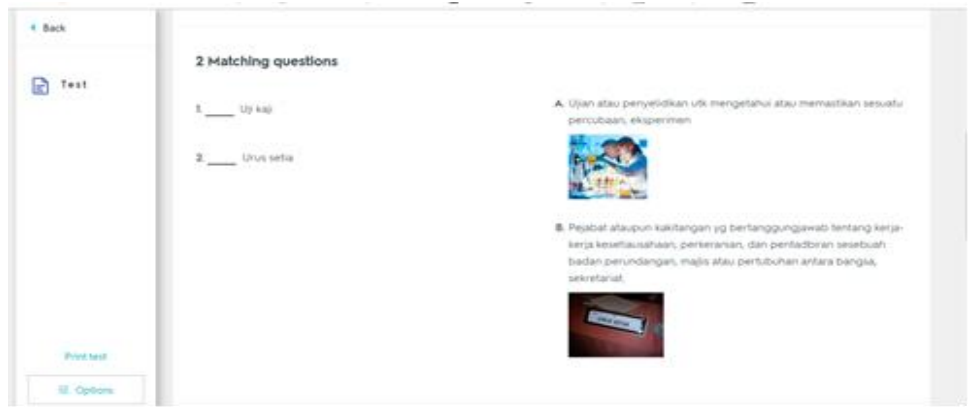

Rajah 12: Skrin Mod 6 (match)

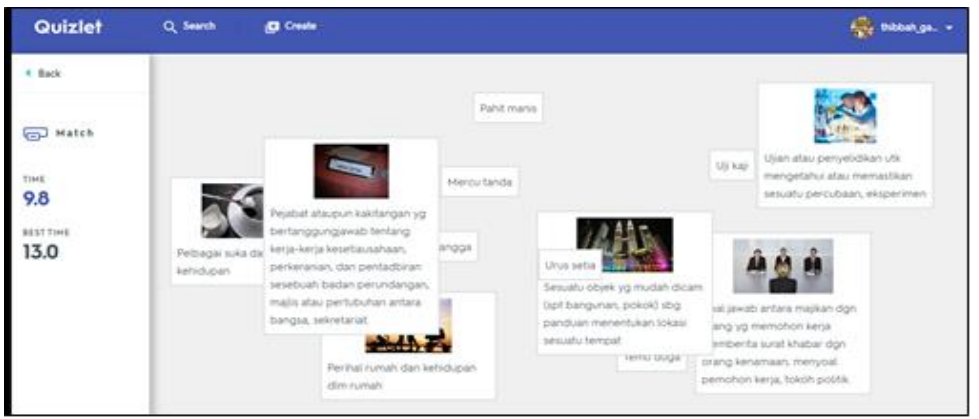

Rajah 13: Skrin Mod 7 (gravity)

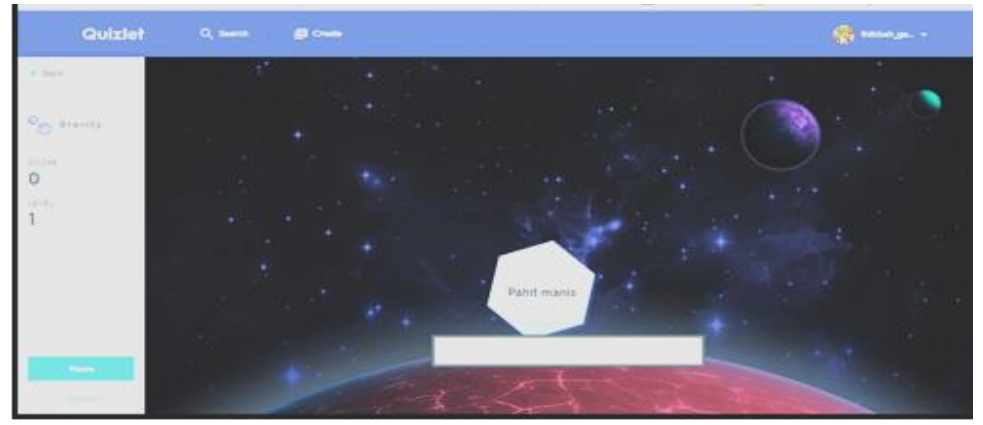


Rajah 14: Skrin Mod 7 (match)

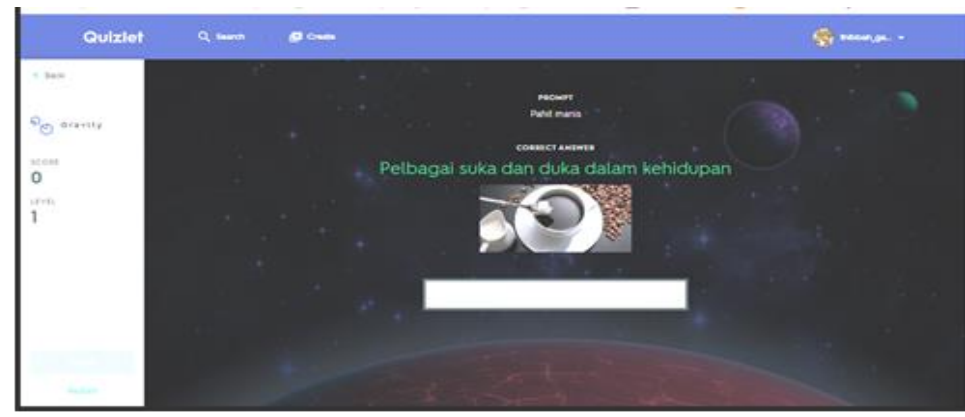

Rajah 15: Skrin Mod 8 (live)

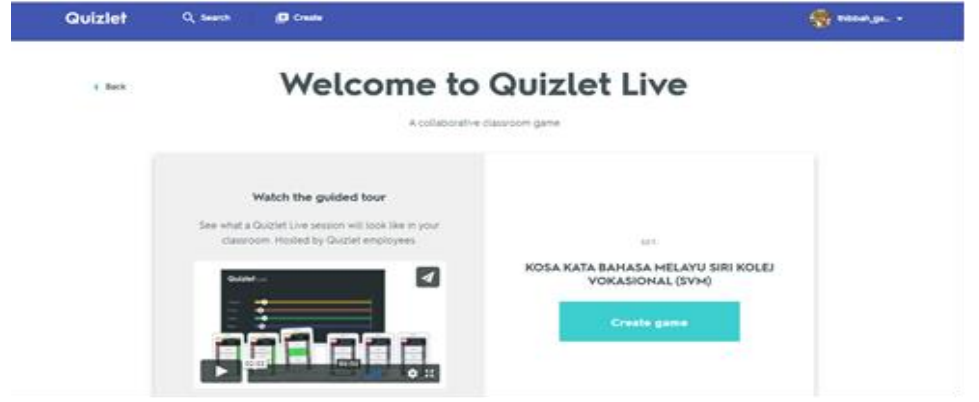

Rajah 16: Skrin Mod 8 (live)

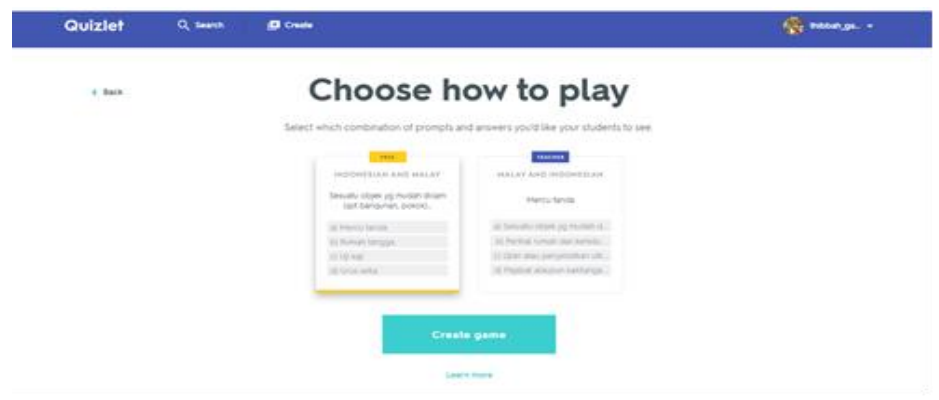

\section{c. Garis Panduan}

Seterusnya ialah proses membina garis panduan kepada pensyarah dan pelajar. Pada peringkat ini, pengkaji menetapkan garis panduan bagi memudahkan pensyarah untuk mengajar dan pelajar untuk belajar menggunakan modul yang dibangunkan. Melalui garis panduan ini pengkaji akan menerangkan secara jelas tentang navigasi serta elemen persembahan bagi setiap skrin aplikasi yang dibangunkan.

\section{d. Kesahan Pakar}

Menurut Pallant (2016), kesahan dilakukan untuk melihat sejauh mana sesuatu alat kajian digunakan untuk mengukur secara tepat terhadap ciri-ciri yang dikaji. Kesahan kandungan Modul Kadimel ini diukur dengan prosedur pengukuran kuantitatif kesahan kandungan oleh Lawshe (1975) iaitu Analisis Nisbah Kesahan Kandungan (Content Validity Ratio atau CVR). Secara keseluruhannya, semua pakar yang dilantik telah mencapai persetujuan bahawa Modul Kadimel mempunyai kesahan kandungan dan muka yang tinggi daan baik. Hal ini dapat dibuktikan apabila semua item mempunyai nilai CVR yang melebihi nilai yang boleh diterima iaitu 0.99 membuktikan Modul Kadimel telah berjaya mencapai matlamat pembangunannya dan berupaya mencapai nilai kesahan yang tinggi. 


\section{e. Ujian Rintis}

Proses yang terakhir dalam fasa pembangunan ialah ujian rintis. Setelah mendapat kesahan pakar, Modul Kadimel diuji kebolehpercayaannya yang bertujuan untuk memastikan aktiviti modul yang dibina boleh diterima pakai dalam jangka masa yang panjang selain memberi kesan kepada pelajar dari segi motivasi dan pencapaian. Dengan ini, pengkaji telah membina soal selidik berdasarkan langkahlangkah aktiviti modul dan soal selidik tersebut diberikan kepada pelajar untuk dijawab setelah mereka mengikuti setiap aktiviti Modul Kadimel sehingga tamat. Soal selidik yang telah diisi oleh pelajar seterusnya dianalisis dengan menggunakan kaedah Alpha Cronbach melalui program SPSS versi 27.0. Nilai Alpha Cronbach berdasarkan pecahan aktiviti modul juga turut dihitungkan. Jadual 3 memperincikan nilai kebolehpercayaan aktiviti Modul Kadimel.

Jadual 3: Nilai kebolehpercayaan aktiviti Modul Kadimel

\begin{tabular}{lc}
\hline \multicolumn{1}{c}{ Aktiviti Modul } & Nilai Kebolehpercayaan \\
\hline Aktiviti 1:Flashcards (kad imbasan) & .82 \\
Aktiviti 2 Learn (latih tubi 1) & .79 \\
Aktiviti 3 Write (latih tubi 2) & .74 \\
Aktiviti 4 : Spell (latihan mengeja) & .90 \\
Aktiviti 5 : Test (penilaian) & .79 \\
Aktiviti 6 : Match (permainan bahasa 1) & .77 \\
Aktiviti 7 : Gravity (permainan bahasa 2) & .70 \\
Aktiviti 8 : Live (permainan kolaboratif) & .87 \\
Aktiviti 9 : Binaan ayat & .78 \\
Keseluruhan nilai Alpha Cronbach & .84 \\
\hline
\end{tabular}

Sebagai kesimpulannya, Modul Kadimel mempunyai kebolehpercayaan aktiviti modul yang tinggi iaitu dengan nilai .84. Dapatan analisis ini membuktikan bahawa setiap aktiviti yang berlandaskan standard kandungan modul telah memenuhi syarat nilai kebolehpercayaan modul iaitu nilai alpha .70 (Jamaludin Ahmad, 2016 dan Fraenkel \& Wallen, 2003). Ini bermakna, hasil analisis telah membuktikan bahawa Modul Kadimel telah siap sedia untuk diuji dari segi kesannya terhadap motivasi dan pencapaian pemahaman pelajar kolej vokasional tahun satu (SVM).

\section{Fasa Pelaksanaan (Implementation)}

Fasa yang keempat ialah fasa pelaksanaan iaitu proses pelaksanaan modul ke atas subjek kajian yang sebenar. Menurut Branch (2009), fasa implementasi terbahagi kepada dua proses iaitu persediaan pensyarah dan persediaan pelajar. Jadual 4 menunjukkan jadual pelaksanaan Modul Kadimel.

Jadual 4: Pelaksanaan Modul Kadimel.

\begin{tabular}{|c|c|c|}
\hline Minggu & Perkara & Bahan \\
\hline \multirow[t]{3}{*}{1} & 1. Taklimat Pelaksanaan Modul Kadimel kepada pelajc & \\
\hline & 2. Edaran Borang Maklumat dan Keizinan Peserta & Borang Maklumat \& Keizinan \\
\hline & 3. Pelaksanaan Ujian Pra & Peserta Kertas Ujian Pra \\
\hline 2 & PdP berdasarkan Modul Kadimel (Unit 1) & $\begin{array}{l}\text { Manual dan Modul Kadimel } \\
\text { Aplikasi Quizlet }\end{array}$ \\
\hline 3 & PdP berdasarkan Modul Kadimel (Unit 2) & $\begin{array}{l}\text { Manual dan Modul Kadimel } \\
\text { Aplikasi Quizlet }\end{array}$ \\
\hline 4 & PdP berdasarkan Modul Kadimel (Unit 3) & $\begin{array}{l}\text { Manual dan Modul Kadimel } \\
\text { Aplikasi Quizlet }\end{array}$ \\
\hline 5 & Pelaksanaan Ujian Pos & Kertas Ujian Pos \\
\hline 5 & $\begin{array}{c}\text { Pelaksanaan soal selidik -Borang soal selidik } \\
\text { motivasi (ARCS) }\end{array}$ & $\begin{array}{l}\text { Borang soal selidik motivasi } \\
\text { (ARCS) }\end{array}$ \\
\hline 11 & Pelaksanaan Ujian Pos Lanjutan & Kertas Ujian Pos Lanjutan \\
\hline
\end{tabular}


Jadual 4 menjelaskan jadual pelaksanaan Modul Kadimel iaitu ujian pra diberikan seminggu sebelum intervensi diberikan. Intervensi akan berjalan selama 3 minggu. Seterusnya, ujian pos dan soal selidik diberikan seminggu selepas intervensi tamat manakala ujian pos lanjutan diberikan enam minggu selepas intervensi tamat bagi mengenal pasti pengekalan terhadap intervensi tersebut dan juga untuk mengelakkan carry-over effect. Data dikumpulkan dan dianalisis selepas intervensi selesai dilaksanakan.

\section{Fasa Penilaian (Evaluation)}

Fasa yang terakhir ialah fasa penilaian yang merangkumi proses penilaian ke atas keberkesanan modul sebelum dan selepas dilaksanakan. Penilaian perlu dibuat secara berterusan dan bersepadu pada semua peringkat untuk mengetahui keberkesanan Modul Kadimel. Modul ini telah dilaksanakan dan daripada pelaksanaan tersebut, terbukti modul ini berjaya menangani permasalahan yang berlaku. Untuk tujuan mengukur keberkesanan modul ini, ujian pra-ujian pos satu kumpulan telah dijalankan. Hasil pencapaian daripada ketiga-tiga ujian dianalisis bagi melihat perbezaan pencapaian sebelum dan selepas intervensi. Analisis statistik deskriptif (seperti dalam jadual 5) dilakukan bagi mengenal pasti nilai min, sisihan piawai, nilai minimum dan nilai maksimum ujian pra, ujian pos dan ujian pos lanjutan bagi subjek Bahasa Melayu dalam kalangan pelajar vokasional tahun satu yang menggunakan Modul Kadimel.

Jadual 5: Deskripsi Min, Sisihan Piawai, Minimum dan Maksimum, Skewness dan Kurtosis Secara Keseluruhan Ujian Pra, Ujian Pos dan Ujian Pos Lanjutan bagi Subjek Bahasa Melayu

\begin{tabular}{lccc}
\hline & Ujian Pra & Ujian Pos & Ujian Pos Lanjutan \\
\hline $\mathrm{N}$ & 63 & 63 & 63 \\
Min & 15.19 & 17.98 & 18.57 \\
Sisihan Piawai & 3.63 & 2.83 & 2.98 \\
Minimum & 6 & 10 & 11 \\
Maksimum & 24 & 24 & 24 \\
Skewness & -.23 & -.55 & -.71 \\
Kurtosis & .12 & .34 & .22 \\
\hline
\end{tabular}

Dapatan menunjukkan min skor ujian pra ialah 15.19, min skor ujian pos ialah 17.98 dan min ujian pos lanjutan ialah 18.57. Hal ini bermakna terdapat peningkatan min skor ujian sebelum intervensi dan selepas intervensi. Hal ini bermaksud pembangunan modul berbantukan multimedia memberi kesan yang signifikan bagi motivasi dan juga pencapaian kosa kata pelajar. Justeru, hal ini bukan sahaja menunjukkan peningkatan pencapaian malah keputusan menunjukkan ketekalan ingatan dalam pencapaian kosa kata dalam kalangan pelajar tahun satu kolej vokasional.

\section{Kesimpulan}

Secara keseluruhannya, proses pembangunan Modul Kadimel telah melalui fasa-fasa yang sistematik dan teratur berdasarkan Model ADDIE. Modul Kadimel yang dibangunkan ini jelas terbukti mempunyai kesahan yang baik dan nilai kebolehpercayaan yang tinggi. Model ini juga sesuai dijadikan sebagai panduan dalam proses pembangunan kerana modul ini merupakan modul multimedia yang melibatkan penggunaan TMK dengan sokongan bahan-bahan bercetak yang terdiri daripada modul aktiviti pelajar dan modul panduan pensyarah (Jamaludin, 2016). Kesimpulannya, dapatan kajian ini menunjukkan pembelajaran multimedia yang interaktif berasaskan modul mampu meningkatkan pencapaian pelajar yang seterusnya akan memperlihatkan pengekalan pencapaian kosa kata pelajar dalam subjek Bahasa Melayu. Ini membuktikan kaedah alternatif ini berkesan bagi meningkatkan pencapaian pelajar dari segi pemahaman dan perluasan kosa kata. Selain itu, kaedah pembelajaran ini juga dilihat memberi impak yang positif ke atas ketekalan ingatan pelajar terhadap ilmu yang diperoleh dalam jangka masa yang panjang. 


\section{Rujukan}

Amelia Leong Chiew Har. (2017). Vocabulary Learning Among Young ESL Learners Using TabletBased Digital Storytelling. (Doctoral dissertation). Universiti Sains Malaysia, Pulau Pinang.

Baity. (2019). Pembangunan dan Kesan Modul Multimedia Interaktif Membuat Pakaian (MIMP) terhadap Terhadap Pencapaian, Ketekalan Ingatan dan Motivasi. (Doktor Falsafah). Fakulti Teknikal dan Vokasional : Universiti Pendidikan Sultan Idris.

Branch, R. M. (2009). Instructional design: The ADDIE approach (Vol. 722). UK: Springer Science \& Business Media.

Dewi Kartika Sudirman \& Sharifah Hafsah Mohamed Hanifa (2018). Keberkesanan App Bitara Kata dalam Pembelajaran Kosa Kata. Seminar Bahasa Melayu.78-95.

Farisa Jazima Yusof, Nurul Ashikin Abu Bakar, \& Syamaizar Bilah (2018). English language proficiency among technical students of Kolej Kemahiran Tinggi Mara. Human Sustainability Procedia.

Fatimah Jafri. (2017). Penggunaan Instruksional Teknologi Maklumatdan Komunikasi (TMK) terhadap Mata Pelajaran Teras (Degree dissertation). Universiti Tun Hussein Onn Malaysia, Batu Pahat.

Fraenkel, J. R. \& Wallen, N. E. (2003). How To Design and Evaluate Research In Education. (5 ${ }^{\text {th }}$ edition). Singapore: McGraw-Hill.

Hung, I. C, Kinshuk, Chen, N. S. (2018). Embodied interactive video lectures for improving learning comprehension and retention. Computers \& Education, 117, 116-131.

Jamaliah Jamaludin. (2014). Kesediaan guru kolej vokasional dalam pengajaran amali teknologi elektronik di Negeri Pahang (Doctoral dissertation). Universiti Tun Hussein Onn Malaysia, Batu Pahat.

Jamaludin Ahmad. (2016). Modul Motivasi Diri (ed.ke-3). Kuala Lumpur: Dewan Bahasa dan Pustaka.

Kementerian Pendidikan Malaysia. (2018). Kurikulum Standard Kolej Vokasional Bahasa Melayu, Dokumen Standard Kurikulum dan Pentaksiran Semester 1- 4. Putrajaya: Bahagian Pendidikan Guru.

Lai, L. C. (2017). Pembangunan dan penilaian modul penulisan karangan Bahasa Melayu Tingkatan Empat/Lai Lee Chung (Doctoral dissertation). University of Malaya, Kuala Lumpur.

Lawshe, C. H. (1975). A quantitative approach to content validity. Personnel Psychology, 28(4), 563575.

Lembaga Peperiksaan Malaysia. (2017). Laporan prestasi calon bagi kertas bahasa Melayu SPM. Kementerian Pendidikan Malaysia.

Mahalechumy Narayanansamy. (2015). The Effects Of Sms-Based Learning Towards Undergraduates' Motivation And Performance. (Doctoral dissertation). Universiti Sains Malaysia, Pulau Pinang.

Mayer R. E. \& Moreno R. (2003). Nine Ways to Reduce Cognitive Load in Multimedia Learning. Educational Psychologist, 38, 43-52.

Mayer R. E. (2014). The Cambridge Handbook of Multimedia Learning (2nd ed.). New York: Cambridge University Press.

Mohd Jalil, A., Noor Hisham, J., \& Annas Akhmal, H. (2015). TVET di Malaysia: cabaran dan harapan. Seminar Kebangsaan Majlis Dekan-dekan Pendidikan Awam (pp. 340-346). Batu Pahat:Fakulti Pendidikan Teknikal dan Vokasional, UTHM.

Nagy, W. (2007). Metalinguistic awareness and the vocabulary-comprehension connection. Vocabulary acquisition. Implications for reading comprehension,52-77.

Nailul Azmi Ismail \& Zaleha Ahmad (2017). Keberkesanan penggunaan quizlet dan kahoot IT dalam memperkasakan pengajaran guru dan memperkaya pembelajaran murid. GSE E-Journal of Education, 5, 33-43.

Noorizah Mohd. Noor \& Zaini Amir (2009). Exploring the vocabulary learning strategies of EFL learners. Language and Culture: Creating and Fostering Global Communities. 7th International Confronce by the School of Studies and Lingustics Faculty of Social Sciences and Humanities, 313-327. Diperolehi dari http://www.ukm.my/solls09/Proceeding/PDF/noorizah $\% 20$ and\%20zaini.pdf 
Norlizawaty Baharin (2019). Penggunaan Ipad untuk meningkatkan pembelajaran dan penglibatan murid dalam bilik darjah. Jurnal Penyelidikan Pendidikan, 20, $12-24$.

Nur Fatin Shamimi Che Ibrahim, Nur Farahkhanna Mohd Rusli1, Mohd Ra'in Shaari \& Kesavan Nallalutha (2021). Persepsi pelajar terhadap aplikasi multimedia interaktif dalam proses pengajaran dan pembelajaran abad ke-21. Online 247 Journal for TVET Practitioners, 6(1), 1524. https://publisher.uthm.edu.my/ojs/index.php/oj-tp/article/view/6569/.

Nur Shakirah Azizan \& Muhammad Saiful Haq Hussin. (2017). Penguasaan asas membaca Bahasa Melayu melalui program linus di utara Semenanjung Malaysia (Tesis Sarjana). Jurnal Pengajian Melayu, 28(1), 135-163.

Nurulhuda Mohd Sukri (2013). Tahap kesediaan guru terhadap pelaksanaan pembelajaran berasaskan kompetensi di Kolej Vokasional (Tesis Sarjana, Universiti Teknologi Malaysia).

Pallant, J. (2010). SPSS Survival Manual (4th ed.). Crows West, New South Wales.

Roslina Mohd Rasdi. (2009). Vocabulary learning and teaching through student teacher negotiations in the Malaysian ESL classroom (Master's thesis). Universiti Putra Malaysia, Selangor.

Sarimah Ibrahim. (2015). Motivasi Pelajar Dalam Pembelajaran Bahasa Melayu Menggunakan Teknologi Multimedia Pada Abad Ke-21. Diperolehi dari https://ir.unimas.my/id/eprint/13553/

Sedita, Joan. (2005). Effective Vocabulary Instruction. Insights on Learning Disabilities, 2(1), 33-45.

Siti Masrah Sulakah. (2017). Aplikasi Padlet Dalam Pengajaran Dan Pembelajaran Komponen Sastera (Komsas) (Tesis Sarjana), Universiti Tun Hussein Onn Malaysia.

Sriadhi. (2015). Pembangunan dan Penilaian Keberkesanan Koswer Multimedia Dalam Pembelajaran Tenaga Elektrik. ((Doktor Falsafah). Fakulti Teknologi: Universiti Sains Malaysia.

Usha N. \& Vijayaletchumy S. (2019). Strategi kemahiran membaca dalam kalangan murid SJK(T). Jurnal Penyelidikan Pendidikan, 20, 36-52.

Vargas, J. M. (2011). Modern learning: Quizlet in the social studies classroom (Doctoral dissertation, Wichita State University, US).

Wan Azlina Wan Azman. (2017). The effects of multimedia and modality principles on vocabulary learning among form four students (Doctoral dissertation). Universiti Sains Malaysia, Pulau Pinang.

Wilkins, D.A. (1972). Linguistics in Language Teaching. London: Edward Arnold.

Yaacob, A., Shapii, A., Saad Alobaisy, A., Al-Rahmi, W. M., Al-Dheleai, Y. M.,Yahaya, N., \& Alamri, M. M. (2019). Vocabulary Learning Strategies Through Secondary Students at Saudi School in Malaysia. SAGE Open, 9(1), 2158244019835935.

Zaliza Mohamad Nasir \& Zaitul Azma Zainon Hamzah (2014). Sikap dan motivasi pelajar terhadap pembelajaran Bahasa Melayu. Procedia-Social and Behavioral Sciences, 134, 408-415. 